\title{
Лексичні засоби позначення дитячого віку в писемних пам'ятках української мови XVI-XVIII ст.
}

\author{
ОКСАНА ЗЕЛІНСЬКА \\ Кафедра української мови та методики ії̈ навчання, Уманський державний педагогічний \\ університет імені Павла Тичини, к. 304, вул. Садова, 28, UA-20300 Умань \\ E-mail: zelinska67@ukr.net
}

(Received: 18 March 2019; accepted: 7 June 2019)

Тема дітей і дитинства в різні періоди розвитку суспільного життя була об'єктом глибокого різноаспектного зацікавлення багатьох науковців. Наріжним каменем, за висловом українського історика I. Сердюка, для всіх дослідників дитинства стала книга французького дослідника Ф. Ар'єса «Дитина і сімейне життя за старих часів», що вийшла друком у 1960 р. і виконала роль інтелектуальної провокації та зумовила справжній бум відповідних студій (СЕРдюк 2018: 21). Ф. Ар'єс на прикладі домодерної Франції переконливо доводив, що середньовічне суспільство не виокремлювало дитини зі світу дорослих і сприймало ії не як особу з особливим внутрішнім світом, психікою, потребами, а як «молодого дорослого». Тривалість періоду дитинства була дуже короткою і загалом обмежувалася часом, коли малесенька людина зовсім не могла обходитися без допомоги дорослих. Сучасна модель сприйняття дитинства, на переконання дослідника, почала формуватися аж із кінця XVIII ст. 3 появою освіти, спеціальних суспільних інституцій, змінами правової свідомості (АРьЕс 1999: 8). Із висновками французького вченого корелюють результати спостережень польської дослідниці, яка описала в монографії життя дитини від середніх віків до XVIII ст. (ŻoŁĄDź-STRZELCZYK 2002), українського науковця I. Сердюка, який власне бачення історії українського суспільства XVIII ст. виклав у книзі з промовистою назвою «Маленький дорослий. Дитина й дитинство у Гетьманщині XVIII ст.» (СЕРдюК 2018).

Досліджуючи специфіку сприйняття дитини і дитинства суспільством у різні історичні епохи, науковці прагнуть встановити межі дитинства, час настання дорослості та визначити вікові періоди в межах дитячого віку. 3 цього приводу К. Захарова слушно зауважила, що в більшості випадків періоди життя співвідносилися не 3 біологічним віком, а із соціальними ролями людей і формувалися під впливом соціальних інститутів (ЗАХАРОВА 2017: 81). Для сучасного суспільства звичним $є$ поділ дитячого віку на періоди, які співвідносять передусім із функціонуванням освітньо-виховних інституцій. 
Загальновживаними є назви як самих періодів, наприклад ясельний вік, дошкільний вік, молодший шкільний вік, старший шкільний вік, так і назви осіб (дошкільник, дошкільня, школяр), однак для мовців у досліджуваний період ще не існувало таких критеріїв. Описуючи реалії дитинства в Україні XVIII ст., I. Сердюк акцентує, що сучасні вікові періодизації не можна застосовувати до ранньомодерної доби, коли дитина жила в іншому соціальному та психологічному середовищі, не зазнавала впливу школи, тому вона не вписується в сучасні схеми поділу дитинства на вікові періоди (АРьЕС 1999: 40, СЕРдЮК 2018: 45).

Аналізуючи феномен дитинства, науковці побіжно торкаються і питань номінації окремих періодів дитячого віку. Ф. Ар'єс зазначає, що в повсякденний ужиток входили назви, засвоєні з давніх наукових трактатів, однак зауважує, що коли постала потреба перекласти античні праці з латинської мови на французьку, то в останній забракло слів: до семи латинських назв на позначення періодів людського життя у французькій мові знайшлося тільки три відповідники - дитинство, молодість, cmapicmь. Крім того, молодість усвідомлювалась як зрілий вік, тому для юності не залишалося місця.

Аналізуючи французьку мову XVII ст., Ф. Ар’єс констатує, що в ній не вистачало слів для відокремлення зовсім малих дітей від старших, так само було і в англійській мові. Розмитими в мовному вираженні були межі між підлітковим періодом і юністю та між юністю і молодістю. Ще одне цікаве зауваження французького дослідника стосується того, що поняття дитинства пов'язували передусім із поняттям залежності, а тому дитинство завершувалося тоді, коли відбувалося зменшення залежності (АРьЕс 1999: 37-40). Розробляючи тему дитинства на українському матеріалі, історик I. Сердюк також принагідно торкається питань називання вікових періодів дитинства i припускає, що різні дискурси мали власні лексичні набори для маркування дитячого віку. Ці дискурси дослідник розрізняє у площині вченої і традиційної культур (СЕРдюк 2018: 57).

У цій статті проаналізуємо, які лексичні засоби уживались у писемних пам'ятках української мови XVI-XVIII ст. для позначення дитячого віку та як вони відображали уявлення про вікову диференціацію дитинства.

Джерелами для дослідження стали різножанрові писемні пам'ятки української мови названого періоду: пам'ятки ділової мови, лексикон П. Беринди, твори П. Могили, І. Гізеля, релігійні тексти, проповіді І. Галятовського, А. Радивиловського, поетичні твори.

Передусім зазначимо, що роль маркерів дитячого віку виконували лексеми на позначення дітей: це спільнослов'янська лексема дітu (ЕСУМ 2: 93), дътищ, дътище (СУМ XVI-XVII 8: 26), етимологічно споріднені дитя і дитина (ЕСУМ 2: 79) та численні деривати. Синонімічний ряд на позначення дітей в українській літературній мові кількісно розширювався за рахунок церковнослов'янської мови, яка мала вагомий вплив на розвиток східнослов'янських мов (ЗолтАн 2014: 14). У писемних пам'ятках, крім загальнонародних назв, уживалися засвоєні з церковнослов'янської мови лексеми: младенеи, 
отрок, отроча, отрощзищ, отрощчище, отроковиця, чадо. Більшість назв на позначення дітей, засвоєних з церковнослов'янської мови слів, не збереглася в активному вжитку в українській мові, але з різними лексико-семантичними відтінками побутують у російській мові (КозыРев 1968: 213). Писемні пам'ятки засвідчують активне використання зменшувально-пестливих форм: дітки, дітоньки, діточки, дитятко, отрочок, отрочатко.

Вивчаючи історію дитинства в Україні за часів Гетьманщини, І. Сердюк одним із завдань окреслив встановити не тільки вікову межу, з якої дитина перестає бути дитиною, а й визначити час, коли вона сприймається як дитина. Дослідник констатує, що уявлення тогочасного соціуму грунтувалися на положеннях Святого Письма і середньовічній європейській спадщині. Передусім учений звернувся до правових документів, згідно $з$ якими в українському суспільстві дитина набувала такого статусу одразу після того, як ставало відомо про вагітність жінки. І. Сердюк зазначає, що норми Литовського статуту (розділ 11) захищали дитину ще до іiі народження, в лоні матері дитина набувала майнових прав, а в артикулі 15 було передбачено відповідальність за шкоду, завдану вагітній, унаслідок чого вона втратила дитину (СЕРДЮК 2018: 47, 50).

На лексичному рівні сприйняття початку дитячого віку ще до народження виявляється в тому, що для номінації народженої і ненародженої дитини вживали ті ж самі слова. Наведемо для прикладу фрагмент із Пересопницького євангелія (1556-1561 рр.), що є першим відомим перекладом канонічного тексту українською книжнописемною мовою. У євангельському оповіданні ще ненароджену дитину вагітної Слизавети названо словами младенець і отроча, які в українській літературній мові того періоду уживались як загальні назви на позначення дітей: «И сталось коли оусльїшала иєлисавєеа поздоровлєна Фт м̈рїи. РозыгралсА младєнєц̧ь в животђ єи. И наполниласА Дха стого єлисавєь. И вьзопила голосомь вєликимь рєкоучи. Бл(с)вєна ты в жєнахь. И бл(с)вєнь плод живота твоєго. Бо коли стальсА голось поздоровлєнА твоєго розыгралосА Фтроча в животђ моємь» (ПЄ 250). У цій же цитаті зі Святого Письма автор Нягівських повчань уживає слово дитина: «Коли учула ЕлисавеӨа привътъ Маріинъ, изигралася дътина у чревђ еи» (Няг. повч. 49). Назва отроча на позначення ненародженої дитини засвідчена в богослужбовому тексті «Требнику» П. Могили (1646р.): «Никтоже въ чревђ матернъмъ затворенное отроча Крестити да дерзнет» (Мог., Требник 1: 31). У пам'ятці ділової мови батько називає майбутню дитину дитятком: «Злецаю... у в опеку и в оборону жону мою Раину... и дети мои сына Александра и дочки Федору и Богдану и тое дитятко мое, которымъ жона моя бременна ходить...» (ВГ 182).

Далі розглянемо, які назви в писемних пам'ятках української мови відображають уявлення про дитячий вік і його підперіоди після народження дитини. Цікаві спостереження про обгрунтування в давні часи вікової періодизації людського життя знаходимо у праці французького вченого Ф. Ар'єса. Дослідник зазначає, що автори середньовічних трактатів приділяли велику 
увагу розробці теми вікових періодів. Їхнє виокремлення пов'язували переважно із символікою чисел: наприклад, сім періодів пов'язували з кількістю планет, дванадцять - зі знаками зодіаку та кількістю місяців у році, чотири періоди - з чотирма елементами, чотирма темпераментами, чотирма порами року. Категорії антично-середньовічної науки увійшли в повсякденність: стихії, типи темпераментів, планети та їхній астрологічний зміст, символіка чисел (АРьЕс 1999: 30-36). Поділ людського віку, кратний семи, подав Гіппократ, виокремлюючи сім стадій: перша - дитина, вік до семи років, кожна наступна була кратна семи; підліток - до 14 років $(7 \times 2)$; юнак - до 21 року $(7 \times 3)$; молода людина - до 28 років $(7 \times 4) ;$ муж - до 49 років $(7 \times 7) ;$ літня людина - до 56 років $(7 \times 8)$ і останній віковий період - cmaрicmь (ГиППоКРАТ 1944: 434).

Багато зразків періодизацій людського життя 3 праць середньовічних учених наводить історик Т. Гошко: французький лікар і доктор медицини Бернар де Гордон (1270-1330) у «Liber de Conservatione Vitae Humanae», виданому 1308 р., поділяє людське життя на три періоди, перший з яких Aetas pueritiae - від народження до 14 років, другий - від 14 до 35 років; третій Aetas senectutis - від 35 років до кінця життя. У XIII ст. Філіп Новарський у трактаті «Чотири віки людини» проводив паралель між етапами людського життя і порами року (Гошко 2017: 37). Найчастіше, зазначає дослідниця, в середньовічних теоріях крайні дати окремих періодів людського життя були кратними семи, рідше іншим числам, що мали символічне значення. Т. Гошко подає відомості із середньовічного трактату «Велике зібрання всілякого роду речей», у якому визначено: «Перший вік - дитинство (enfance), починається 3 народження дитини і продовжується до семи років, в цьому віці всяка істота називається немовлям, тому що в цьому віці вона не вміє ні говорити, ні складати досконало фрази; за дитинством іде другий вік, який називається pueritia, і називають його так, тому що людина в цьому віці схожа на зіницю ока, і триває цей вік до чотирнадцяти років. Потім приходить черга третього віку, який називається отроцтвом (adolescence) і триває до 21 року. У трактаті Ісидора Севільського виділено шість періодів: вік немовляти триває до семи років, дитинство - до 14, період дорослішання - до 28 років, зрілість у людини наступає у 50 років, а у 70 - старість» (Гошко 2017: 37). Із представленого в публікації Т. Гошко матеріалу постає, що не кожен середньовічний книжник виокремлював підперіоди саме в межах дитячого віку.

В українських пам'ятках писемності матеріал про поділ людського життя на періоди, включаючи дитячий вік, та назви, що їм відповідають, знаходимо в «Лексиконі славенороському» Памво Беринди (Київ, 1627 р.). У перекладній частині автор найвизначнішого староукраїнського словника тлумачить реєстрові слова на позначення людини певного віку як назви одного «із семи ступенів життя людського». Межі вікових періодів у лексиконі співвіднесено з назвами осіб відповідного віку (кількість років позначено в пам'ятці кириличними літерами). Реєстрове младенец Памво Беринда перекладає синонімами отроча, дитя або виросток льт $\overrightarrow{2}$ (трьох років) і додає вказівку, 
що це перший віковий ступінь життя людини: «Первый степень от седми чЛчкаго житія» (ЛБ 64). До реєстрового отрочищъ П. Беринда подає тлумачення, що це млоденец дев'яти років і є третім ступенем людського життя: «두 стен ч що дорівнював дванадияти рокам, задокументовано лексему отрок: «выросток, пахоля, пахолок, ві льт $\vec{\partial}$ стенн чл̆ч жи(т)» (ЛБ 154). П'ятому періоду - 15 рокам - відповідає реєстрове юноша, яке в перекладній частині пояснено словами млоденец, молодец, парубок і зазначено, що це «пятый степень от седми чл̈чкаго житія». Лексикограф також указує, що за іншими джерелами цей вік становить 20 років (ЛБ 159). У реєстрі словника зафіксовано лексему на позначення шестирічної дитини: «Дьтищъ значить быти льт $\overrightarrow{\mathrm{s}}$ », що $\epsilon$, очевидно, другим віковим періодом (ЛБ 34 ).

Отже, П’ять із семи наведених у лексиконі П. Беринди ступенів людського життя є віковими періодами, виокремленими в межах дитячого віку. Кожному періоду в реєстровій частині словника відповідає така церковнослов'янська лексема: дитина 1-3 років - младенец (отроча, дитя, виросток), 3-6 років - дътищъ, 6-9 років - отрочищ, 9-12 років - отрок, 12-15 (20) років - юноша. П. Беринда подав цю періодизацію, дотримуючись теорії Максима Грека про поділ людського життя на сім окремих періодів, які святогорець виклав у праці «Седмь степеней человъческаго житіа» (НІмчук 1980: 126). Однак перекладна частина словника, що фіксує українську лексику, не засвідчує чіткої кореляції назв дитини з етапами іiі дорослішання.

Проаналізований матеріал писемних пам'яток показує, що лише кілька назв відображали вікову градацію і були закріплені як спеціальні найменування осіб одного визначеного віку і не вживалися на позначення іншого. До них належать лексичні одиниці, якими називали новонароджену і грудну дитину. На позначення дитини, яка нещодавно народилася, у пам'ятках засвідчено словосполучення в церковнослов'янському варіанті новорожденнылй младенецъ: «По ржстве... въ осмый Д̆нь приносится новорожденный младенецъ от бабы к Цркви» (Мог., Требник 1: 46); «Яко новорожденные мл̈днии, словесное небесное млеко возлюбите» (Рад., Вінець рн̈а зв). Субстантивом новонароджений «людина, яка недавно або тільки що народилася» послуговуються в українській мові і нині, але в тлумаченні не зазначено, коли саме завершується період новонародженості (СУМ 5: 435). За церковною традицією, період новонародженості, вірогідно, завершувався часом, коли вже необхідно було охрестити дитину, тобто через сорок днів після народження: «В четирдесять дній младенець законному храму принесеній» (Мог., Требник 1: 50). Період до хрещення К. Смолярек визначає як перший етап життя людини (SMOLAREK 2013: 209).

На позначення грудної дитини пам'ятки документують лексеми 3 прозорою мотивацією немовя і немовятко: «Разбойник един... яко обачил немовлятко Ісуса и матку его Марію, єго носячую... 3 драпъжного звъра отмђнился в скромного и тихого баранка» (Рад., Опов. 209); «Немовлтка засе же мают быти окрещени... не чекаючи съвершенныхъ льт и в зросту» (Мог., 
Требник 1: 905), вони відомі і в сучасній мові зі значенням «дитина, яка ще не вміс говорити; грудна дитина» (СУМ 5: 338). Отже, тлумачення, подане в сучасному словнику, поєднує щонайменше два вікові періоди - грудної дитини і період, коли дитина ще не навчилася говорити, але вже перестала бути грудною.

Колоритною і прозоро мотивованою на позначення дитини грудного віку є лексема пеленчатко, зафіксована в «Лексиконі» П. Беринди в перекладній частині до реєстрового церковнослов'янського слова дътище (ЛБ 34), проте іiі досі не вдалося виявити в інших пам'ятках. С. Тимченко у «Матеріалах до словника» реєструє це слово, але ілюструє його тільки прикладом із лексикону П. Беринди (Тимч., Матер. 2: 40).

Назви осіб за віком представлено в пам'ятці богослужбової літератури «Требнику» П. Могили. Автор їх подає, викладаючи порядок здійснення церковних чинів хрещення, поховання тощо. Для номінації грудної дитини П. Могила обирає лексему младенеи і додає коментар, що цей віковий період триває, поки дитина не вміє говорити: «Младенци нарицаются дъти ссущїи млеко доколиже глаголати не могут» (Мог., Требник 1: 649). Однак у широкому вжитку назва младенеи не була ототожнена саме 3 цим віком, про що йтиметься у статті далі. На позначення немовляти П. Могила вживає також варіант младя: «БЛви настоящее младя и на главу его блвение твое да снидетъ» (Мог., Требник 1: 96); «Влдко Гди Вседержителю, исцелААй всяк недуг... днесь родившую рабу твою исцели... и сего младенца его же породи... помилуй ю и отроча по вълицей мл(с)ти твоей... и изъ нея рожденное $м л а д я$, сподоби поклонитися земному храму» (Мог., Требник 1: 43-44). І. Срезневський у «Матеріалах...» до реєстрового младя подає відповідник младенеи (Срезн. 2: 158).

У сумарії з Пересопницького євангелія до глави, в якій ідеться про благословіння дітей, перекладач уживає зменшувальну форму младенчик і додає вказівку, що це діти, які ще не вміли говорити: «Св(г)листа виписоуєт якь $\overrightarrow{\mathrm{x}}$ младєнчики которий єщє нє мовили ку собъ пригорьтає» (ПЄ 291). Отже, наведені контексти з пам'яток засвідчують, що мовці виокремлювали в межах дитинства віковий період від народження до набуття здатності говорити.

Дослідники дитинства пишуть про особливе значення семиріччя як етапу дорослішання дитини, особливо важливим цей період був для релігійної практики. За християнською традицією, до настання семи років дитину вважали безгрішною, такою, що не розрізняє добра і зла, бо має неразсудний $y м$, а після досягнення семи років дитина може піддаватися спокусам і вже повинна сповідатися. Згідно 3 «Требником» П. Могили, якщо дитина помирає у віці після семи років, то отрочищу седмольтному здійснюють інакший чин поховання, ніж дитини молодшої (Мог., Требник 1: 651). Для номінації дітей, які вже навчилися говорити, і до семи років П. Могила вживає однослівну назву отроча, засвоєну з церковнослов'янської мови: «Дъти же нарицаются отрочата Фтколи же глаголати начнут, даже до седмого льта» (Мог., Требник 1: 649). 
Про семирічний рубіж на шляху дорослішання дитини знаходимо відомості у творі І. Гізеля «Мир з Богом чоловіку» (1669 р.), де автор зазначає, що діти до семи років не повинні дотримуватися посту, але наголошує, що після семи років уже не так: «ЛЪта освобождают от поста дђтей ибо дътем при отлученїи от сосецъ предъ седмим льтомъ ослаба в постъ бывает, по седмом же льть не тако» (Гізель 63). Після семи років настає якісно інший етап дорослішання дитини, пов’язаний із ії здатністю усвідомлювати свої вчинки: семирічні діти, за словами І. Гізеля, начинають разумъвати: «Обаче отрочата людей невърныхъ не имуще седми льт, кое время начинають разумЂвати, не достоит да бы были крещены противу воли родителей ихъ» (Гізель 77).

У зв'язку з розвитком освітніх інституцій семиріччя стає віковим періодом для секулярної практики: із семи років діти починали здобувати освіту, про що знаходимо відомості, наприклад, у заповіті В. Загоровського (1577р.): «Кгды ж дътям моим Бог милостивый даст по семи лет, мает ее милость дяка добре учоного и цнотливого способити» (Загор., Дух. зав. 171). На цей факт звертає увагу I. Сердюк, цитуючи висновок із книги про студентів Київської академії: «Семирічний вік фігурує як рубіж, з якого слід було починати перші кроки на шляху здобуття знань» (СЕрдюк 2018: 59).

Останньою стадією дорослішання дитини була юність. У сучасному трактуванні юність визначають як «період життя людини до зрілості, коли відбувається нагромадження й розвиток життєвих сил організму; молодість» (СУМ 11: 614). У писемних пам'ятках на позначення юності засвідчено іменник юність, з яким ототожнено назву особи - юноша та атрибутив юний, що вживався і як субстантив. Вище вже було наведено фрагмент із «Лексикону» Беринди, де реєстрове юноша тлумачено як період життя з 15 років (ЛБ 154).

Промовисту характеристику вікового періоду юності подано у книгах «О воспитании чад» (1609р.) та «Іфіка ієрополитка» (1712р.), де юних осіб порівнюють зі сліпими, а саму юність - із розгнузданим конем: «Якоже нъкій конь сверпый, якоже нъкій звђръ неоукротимый сицева есть юность» (О восп. чад 91); «Сверђпа вещъ есть юность, многихъ требующа настоАтелей, педагшгов въсльдователей; въспитателей. Аще же души отрочате приставити подобает педагога» (О восп. чад 91,94$)$. Проте зауважимо, що і в цих книгах лексеми юность і юний не ототожнюються з чітко окресленим періодом дитинства. У названих творах, що $є$ яскравими репрезентантами тогочасного педагогічного дискурсу, обгрунтовують необхідність виховувати дитину і давати їй освіту: «Ничтоже тако погублАет юных якоже ласканіе и сльпая родителе любов к чадшм» (Іфіка 50); «Сльпоть юныхъ подати искусныхъ вождФвъ поле(з)но и нуж(д)но е(ст) оученїе юным» (Іфіка 50); «В ... училищахъ полезнъе будет юнымъ навыкати всАческаго наказанїА» (Іфіка 50). Назви юний і юність у текстах цих творів $є$ радше загальним позначенням усіх вікових періодів дитинства, а не останнього перед настанням повноліття.

Інші загальні назви на позначення дітей не були співвіднесені з певним віковим періодом у межах дитинства. Наприклад, лексемами младенеиь і omрок (отроча), які сучасний мовець ототожнює з немовлям і підлітком, у па- 
м'ятках української мови називали дітей різного віку. Тексти пам'яток української мови засвідчують, що лексемою младенець і фонетичним полонізмом млоденеи позначали і новонароджених, і старших дітей, наприклад: «А тото вамь знамєнїє. Найдете младеньца пеленами повитого, а положеного въ яслехь. И нашли тамь Марїю Їсосифа и дитя лежачеє въ яслехь. А оузрђвши рославили то што є(ст) имь повьдєно о томь дитяти» (ПЄ 252). За євангельським оповіданням, цар Ірод наказав убити маленьких діток до двох років у Вифлеємі. У переказах цієї історії засвідчено слова млоденции, отрочата: «Млоденци во Вифлеомъ вои убиваютї от сосцу родительных сильно оттерзают» (Вел. 43); «Рогнђвал ся Ирод на вЪщковъ, а з злости и шаленства и з зазрости отрочата позабывати росказалъ» (УС 893); «...От Ирода избїенных младенцех» (Гізель 344). Водночас спостерігаємо, що младенцами називали дітей, які вже відвідували навчальний заклад, наприклад, автор шкільної граматики Л. Зизаній у передмові звертається до младенщев, яких далі називає спудеями (Зиз., Грам. 8). На позначення осіб шкільного віку послуговується цим словом I. Галятовський: «Григорій Трофимович зъ мъста Черньгова будучи млденщем учился в коллегыумъ Києвском Могилеанском» (Галят., Ключ 362). А. Радивиловський у проповіді називає младенечем уже дорослу людину: «Рекл $\overrightarrow{\mathrm{X}}$ до едного богатого младенца...» (Рад., Вінець рмз3). Інший контекст цього ж автора засвідчує синонімію лексем млоденеи і юноша: «Х्Хртос Спситель споткавши ся в брамъ з тьломъ того умерлого млдниа воскрешаеть его мовячи, Юноше, тебе глю востани» (Рад., Вінець іог зв.). К. Зіновіїв младенцем називає особу, яка вже може одружуватися: «В шєстнадцатих льть слушно мл(д)нца жвнити» (Зінов., Вірші 118).

У писемних пам'ятках широко засвідчено засвоєну з церковнослов'янської мови лексему отрок та однокореневі. Наприклад, отроками П. Могила називає дітей, які йтимуть навчатися: «Чи(н) бл(с)венї̈ отрокшвъ въ оучилище» (Мог., Требник 2: čka).

Словом отроча здебільшого номінували новонароджену і грудну дитину, наприклад, у текстах молитов за здоров'я матері і новонародженої дитини чи в описах таїнства хрещення: «Рабу твою, днесь родившую отроча помилуй и из нея рожденнаго младенца соблюди от всякія горести» (Мог., Требник 1: 44); «Раздрђшаеть Ієрєй пояс дътищу... омочаетї въ водъ чистой... и кропить отроча» (Мог. Требник 1: 94); «Аще бы отроча зБло было недужно... тогда должна его сама баба крестити» (Гізель 76). І. Гізель називає omрочам грудну дитину, зазначаючи, що жінкам не треба дотримуватись посту, коли вони вигодовують дитину: «женамъ доящим сосци своими отрочат» (Гізель 63). Однак лексему отроча уживають і на позначення старшої віком дитини, яка вже потребувала цілеспрямованого виховання: «Аще же души отрочате приставити подобает педагога» (О восп. чад 94).

У пам'ятках засвідчено дериват отроковиия на позначення дівчинки. Проповідник А. Радивиловський, переповідаючи притчу з Свангелія від Луки про те, як Ісус воскресив доньку Іаіра, цитує Христові слова: « $\overline{\mathrm{X}}$ руку свою Бзкую вложилъ на умерлую дщеръ... и воскресиль оную мовячи: отроковице 
востани» (Рад., Вінець тді зв.), але цей контекст не дає підстав визначити вік дитини, названої лексемою отроковиця. Указівку на вік - 11 років - подає в поетичному творі К. Зіновіїв: «бєзврємєнно замуж давают дъвицы: въ єдинадєсятых льтєх отроковищыл» (Зінов., Вірші 117). У «Словнику української мови» значення цього слова тлумачать як дівчинка-підліток (СУМ 5: 810).

Переконливим свідченням синонімії назв на позначення дітей і відсутності в їхній семантиці чіткого розрізнення за віковим періодом стає вживання їх у тексті однієї пам'ятки. Наприклад, у статуті Львівської братської школи на позначення дітей, які будуть відвідувати школу, засвідчено назви і загальнонародні, і церковнослов'янські: діти, дітище, дитина, отрок, отрощчuщ: «Дидаскал, взявши порученное ему дътище, маеть его учити с промыслом доброй науки; учити дидаскал и любити маеть дћmu вси заровно; помагати всяким способом дътину ку науць приводити»; «Сходитися мают отрощищща до школи на годину певную; в кожний порану мает пильне смотрити дидаскал еслиби якого отрока не било» (Поряд. шк. 38, 39). Синонімічний ряд засвідчено в книзі «О воспитании чад» (1609р.), на титулі автор уживає лексему чада, а далі використовує синонім дітu: «О въспитанїи $\partial$ bmей... В общую ползу родителемъ и $\partial$ втемъ» (О восп. чад 77-81). У текстах педагогічного призначення лексеми на позначення дітей позначають осіб, які навчаються, а тому стають контекстуальними синонімами до спеціальних найменувань учнів.

Про синонімію назв свідчить зіставлення перекладних текстів. Наприклад, у восьмому біблійному псалмі є рядки, що в сучасному викладі звучать так: «3 уст дітей і немовлят учинив Ти хвалу» (Біблія, Книга Псалмів, псалом 8: 3). Згідно з Свангелієм від Матвія, коли Ісус Христос прибув до Єрусалима й увійшов до храму, то малі діти, побачивши його, вигукнули: «Осанна Сину Давидовому!». Звертаючись до здивованих і розгніваних архієреїв і книжників, Спаситель нагадав їм про старозавітне пророцтво і процитував 8 псалом: «Чи ж ви не читали ніколи: „Із уст немовлят і тих, що ссуть, учинив ти хвалу“» (Біблія, Св. Матв. 16). Отже, у тексті псалма йдеться про грудних дітей і маленьких, які ще не вміли говорити. В Острозькій Біблії (1581р.) у тексті цього псалма на позначення грудної дитини вжито слово ссущчий, а маленької младенещ: «Изъ уст младенец и ссущихх совершил еси хвалу» (Остр. Біблія 1: 575). У новозавітній частині Острозької Біблії дітей, які прославляли Христа, названо отроками, а в прямій мові, що є цитуванням псалма, ужито ті ж лексеми - младенеи і ссущций (Остр. Біблія 2: 372). У Пересопницькому євангелії перекладач у переказі також уживає лексему отрок, а в цитаті з псалма, яку проголосив Ісус, так само младенец і ссущий: «Видівшє жє архиєрєє и книжники чудєса ижє сътвори и отроки зовущаА и глщаА в цркви: Осанна сыну дв(д)ь, гніваючисА рекли єму, слышіш ли што тии моВАТь. А рєкЛЬ им: а чи єстє николи нє читали: изь оусть младєнєцьь и єщє сcущцихь съврьшиль єси хвалу» (ПЄ 178). Отже, процитований матеріал пам'яток засвідчує, що грудних дітей названо церковнослов'янізмом ссущий, який, безперечно, у народній мові не вживався. 
На відносну вікову ознаку дитини вказував ад'єктив малий, який поєднувався з назвами на позначення дітей. Порівняймо контексти, у яких малий ужито стосовно дітей різного віку:

- новонародженої дитини чи грудної дитини: «Єдно дитятко малое, пелюхами повитое, въ колисцъ противъ прироженью своему промовило, же видъло прч(с)тую б̈цу. Потымъ знову тое немоватко умовкло» (Галят., Ключ $262)$; «Въ ВиӨлеемской пещерђ... новорожденного свого царя поклоном учтили... поклонишася пріигравають маленькому дътинцђ, тђшать плачучого...» (Туптало, Проповіді 80);

- трирічної дитини: «Дитятко теж малое, только у трох льтех, образили, зранили» (СУМ XVI-XVII 8: 27);

- контекст, у якому малим названо старшого хлопчика: «ХлопА малое, жегнаючи тую панну кр(стомъ) стымъ выгнал з неи злого духа...» (Галят., Ключ 302).

3 наведених далі характеристик, що є фрагментами з текстів проповідей, можемо стверджувати, що малі - це діти до семи років, бо, згідно з християнською традицією, саме вони ще не розрізняють добра і зла: «Убо мусим признати себђ тое, жесмо грђшнъи єсмы... кромђ малыхъ дътей, которїи не познаютъ єщи а нъ злого, а нъ доброгю» (Семя 43); «У в мальихъ дътехъ не пануеть памятозлобїе...» (Семя 110).

У пам'ятках натрапляємо також на слово малолітній: «Малольтный отрокъ, когда сверсника своего в лучшом одЂянии зобачитъ нђкоеюсь... завистью на него порушается» (Семя 110). Найбільш вірогідно, що малолітніми вважали дітей від семи до чотирнадцяти років. Згаданий у наведеному контексті отрок уже пізнав гріх заздрості, отже, він мав більше, ніж сім років. Нижню межу малоліття можемо встановити за церковною забороною до взяття шлюбу. І. Сердюк зазначав, що важливою ознакою дорослості була можливість брати шлюб (СЕРдюк 2018: 67). Перепоною до взяття шлюбу якраз було малоліття, на позначення якого І.Гізель ужив словосполучення скудость л‡m, зазначивши, що шлюб може брати хлопець після чотирнадцяти років, а дівчина - після дванадцяти: «Препона ест скудость льm, єже возбраняеть супружества... егда женихъ не имать от рождения своего льт четыринадесяти, а невظста дванадесяти» (Гізель 99). Отже, можемо припустити, що малолітні діти - це діти від семи до чотирнадцяти років, такі, які ще не досягли належної фізіологічної зрілості. Поняття про малоліття загалом відповідає і сучасним уявленням. Наприклад, відповідно до сімейного кодексу України, малолітньою вважається дитина до досягнення нею чотирнадцяти років (Сімейний кодекс: стаття 6).

Крім назв осіб, які ототожнюються з дитячим віком, в українських писемних пам'ятках широко представлено назви періоду дитинства. 3-поміж них засвідчено однослівні найменування, виражені абстрактними іменниками дитинство, немовятство: «Избралъ наказаніе и боАзнь Бӝїю єще ватства своегФ» (Рад., Огородок хч̃и). Лексема дитинство була широковживаною в українській мові XVI-XVII ст. (СУМ XVI-XVII 8: 26) і залишилася 
в лексичному складі до сучасного періоду, а іменник немовятство не вдалося виявити в інших пам'ятках.

Крім однослівних назв, уживали словосполучення іменників вік, літа 3 атрибутивами дитинний, млоденческий: «Повъдають в Черньгови обыватели давнїи которіи будучи в дитинном въку... же они малими дњтми будучи од старых продков своихъ науку такую чували» (Галят., Ключ 350); «Я... Илля Иванович... трудами многими от дитинніх льm моихъ ослабълого умом же здроваго» (Док. Маз. 973); «А што ся дотычет хованя сына моего... ховати звлаща в летех детинных в ласковом мл(с)тивои опеце и науце его» (ВГ 161).

Назви більшості вікових періодів життя людини, включаючи і дитячий вік, засвідчено у творах українського проповідника А. Радивиловського: «Ссли уважимъ кождый вђкъ житъА члвчского на семъ свђтђ жадного не машъ которго чллвкъ нарожденний на сей свђт не терпђл якои бђды и скорби. Терпятъ немовятка розныи болђзны, трпят и въку млденческаго и вђку мужескаго и наибарзђй вђку старческаго» (Рад., Вінець ті зв.). 3 наведеного контексту можемо зробити висновок, що автор розрізняє вік, якому відповідала назва немовятко і вък млденческий. В іншому фрагменті тексту проповідник уживає назви немовятство, дитинство і словосполучення молоді літа: «...и як ся $з$ немовятства и дитинства... было призвычаило от того жаднымъ промысломъ отдалити от себе не могло... и отоль есть явно же кто ся до якихъ грђховъ зъ молодыхъ льтъ призвычаъть не будетъ караный... то такъ в тыхъ грђхахъ состарђетъ» (Рад., Вінець їе).

У проповіді А. Радивиловського спостерігаємо використання синонімічного ряду на позначення вікового періоду зі стилістичною метою. У казанні, присвяченому святому Миколаєві, автор прагне вразити слухачів відомостями про те, що Чудотворець виявляв свою святість ще 3 дитинства, і використовує низку назв на позначення цього вікового періоду. Синонімічний ряд, об'єднаний семантикою «дитячий вік», утворюють абстрактні іменники немоватство, дитинство та словосполучення льта млоденческыи, льта немовачыи, млоденческый въкъ, дитиннъ лъта: «Избраль наказаніе и боАзнь Бӝ̈ю єще $\omega($ т) немовАтства своег

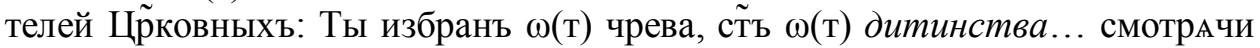
на єго постъ... в льтехъ немовАчихъ, кто не навђлъ же мълъ чудо быти мно-

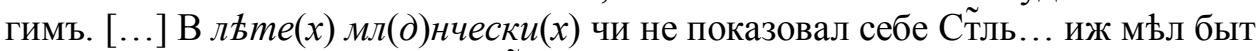
чудо многим. [...] Гды теды стль Нїколае в млоденческомъ своемъ въку не до игръ и пещоть... до цнот себе призвычавалъ» (Рад., Огородок хичи-хчัө); «С тй̆ Пр(о)рк ИлїА єще в дитинных льтех показаль тоє, же рука Г(с)днА бъ на нем» (Рад., Огородок ен̈в).

Поняття про ранній вік людини передавав книжний фразеологізм от младux ногтей, збережений у слов'янських мовах (ЦЕйтлин 1996: 75). На думку педагогічних діячів, уже 3 цього періоду слід починати виховання дитини: «НаставлАть о $(m)$ младыхъ ногтей въ стрась божіи, блггочестіи, й добронравіи» (Перв. уч., Передм. 25). 
У віковій періодизації дитинства важливим є настання дорослості, або повноліття, що зумовлено передусім правовим статусом повнолітньої особи. У досліджуваних текстах назви вікових періодів за диференційною ознакою «повноліття-неповноліття» найширше представлені в пам'ятках ділової мови, зокрема юридичних документах, що засвідчували право на успадкування - тестаментах, або заповітах, бо досягнення повноліття давало право розпоряджатися успадкованим майном. Поняття про повноліття-неповноліття передавали атрибутиви дорослий і недорослий: «Матка моя, оставшися по смерти отца моего вдовою з нами дътми своими недорослими...» (Кн. Пир. 14); «...Лекговано позосталой Катри, в маленьких льтех, недорослой» (Кн. Полт. 74).

На позначення повноліття уживали стійкі словосполучення з компонентом взрост «вік»: взрост лет (дитинних) (СУМ XVI-XVII 4: 28), взрост совершенный: «Прийдет до взросту совершенного дочка моя Мартуся» (Док. Маз. 988), а також словосполучення з церковнослов'янізмом возраст: зуполный возраст, досконалый возраст, совершенный возраст (СУМ XVI-XVII 4: 187).

Вікові особливості дитини за ознакою повнолітній позначали словосполученнями льта зуполные, яке у сполученні з дієсловами дорости, дой$m и$ реалізувало значення «досягнути повноліття»: «Дети мои, дошедши лет свои(х) зуполных...» (ВГ 93); «Тое дитя дойшовши зуполних льт а довыдавшись же жена моя померла... витисла мене 3 того грунту» (Кн. Пир. 124). Іноді атрибутив зі значенням «повнолітній» опускали і значення досягти повноліття виражали словосполученням дорости літ: «А естли бы теж дети мои доросши лет своихъ, хотели тую третюю часть мети...» (ВГ 24). Лексичні одиниці на позначення повноліття засвідчено і поза правовим дискурсом, наприклад: «Сіи въспріемници въ совершенномъ возрасть, а не в дътинномъ изъбрани и припущены быти имутъ» (Мог., Требник 1: 33); «Смерть не допустивши ей до дойзрълого въку позбавила отца всеи надъи...» (Рад., Вінець Т зв.).

Отже, у пам'ятках української мови широко представлено лексичні засоби маркування вікового періоду людського життя - дитинства. Значення «дитячий вік» передусім реалізували загальні назви на позначення дітей, що були надбанням загальнонародної мови та засвоєні з мови церковнослов'янської. Спостерігаємо, що семантика лексем, за допомогою яких маркують дитячий вік, є виразником загальних уявлень про дитинство, спільних для тогочасних українського і європейського соціумів. Незважаючи на доволі широкий синонімічний ряд найменувань дітей, їхня семантика не відображала чіткої градації вікових періодів у межах дитинства, і лише кілька лексем були ототожнені з певним віковим періодом (новорожденний, немовля).

Досліджуваний матеріал підтверджує припущення про те, що різні суспільні практики послуговувались неоднаковим набором лексичних одиниць для маркування дитячого віку. У церковно-релігійній сфері послуговувались здебільшого церковнослов'янською лексикою, яка з великою вірогідністю не 
уживалась у народному мовленні. Для правої сфери важливим було завершення етапу дитинства і настання повноліття, тому лексика на позначення цього вікового періоду найбільше представлена в пам'ятках ділової мови. Тексти педагогічного спрямування насичені як загальнонародною лексикою, так і засвоєною з церковнослов'янської мови, і вводять лексику на позначення дітей у коло номінацій на позначення осіб, які здобувають освіту.

\section{Джерела}

Біблія = Біблія, або Книги Святого Письма Старого й Нового Заповіту. Українське біблійне товариство, 1992.

ВГ = Волинські грамоти XVI cm. Упоряд. В. Б. Задорожний, А. М. Матвієнко. Київ: «Наукова думка», 1995.

Вел. = ВЕличковський І. Твори. Київ: «Наукова думка», 1972.

Галят., Ключ = ГАлятовський І. Ключ розуміння. Київ: «Наукова думка», 1985.

Гізель = ГізеЛь І. Вибрані твори. Т. 1. Кн. 2. Київ-Львів: «Свічадо», 2009.

Док. Маз. = Доба гетьмана Івана Мазепи в документах. Упоряд. С. О. Павленко. Київ: «Києво-Могилянська академія», 2007.

ЕСУМ = Етимологічний словник української мови. Т. 1-6. Київ: «Наукова думка», 1982-2012.

Загор., Дух. зав. = ЗАГоровський В. Духовное завظщание, 1577. В кн.: Украӥнська література XIV-XVI cm. Київ: «Наукова думка», 1988. 167-184.

Зиз., Грам. = Грамматіка словенска. Съвершенна(г) искүства осми частей слова и иных ну(ж)дныl(x). Новюсоста(в)лен(н)а Л. Z. Вільна, 1596.

Зінов., Вірші = Згновлїв К. Вірші. Приповісті посполиті. Київ: «Наукова думка», 1971.

Іфіка = ИӨіка іерополітіка или Філософін НравоүчителнаА сvмволами и приүподоблені изасненна. Київ, 1712.

Кн. Пир. = Пирятинські актові книги. В кн.: Стороженки. Фамильньий архивъ. Т. 6. Київ, 1908. 1-387.

Кн. Полт. = Актовыя книги Полтавскаго городового уряда ХVII въка. Вып. 3. Справы въчистыя 1672-1680 годовъ. Черниговъ: Типографія Г. М. Веселой, 1914.

ЛБ = Лексикон словенороський Памви Беринди. Київ: Видавництво АН УРСР, 1961.

Мог., Требник = МогилА П. Требник. Київ, 1646.

Няг. повч. = Няговские поучения. Факсимильное воспроизведение текста по изданию А. Л. Петрова с вводной статьей Л. Дэже. Ред. А. Золтан. Nyíregyháza: Nyíregyházi Főiskola Ukrán és Ruszin Filológia Tanszék, 2006.

O восп. чад = Иже въ святыхъ Оца нашего Іюанна Златоүстаго. Бесьда избраннаА $\omega$ въспитаніи чадъ. Львів, 1609. В кн.: НАумЕнко Ф. І. Педагог-гуманіст і просвітитель I. М. Борецьккий. Львів: Видавництво університету, 1963. 73-116.

Остр. Біблія = Библіа сиріч книгы Ветхаго и Новаго Завъта по языку словенску. Острог: Друкарня К. К. Острозького, 1581.

Перв. уч. = [Прокопович Ф.] Первое оученїе отршкамъ. Чернігів, 1760.

$\Pi €=$ Пересопницьке Свангеліє. 1556-1561. Дослідження. Транслітерований текст. Словопокажчик. Вид. підг. І. П. Чепіга. Київ, 2001.

Поряд. шк. = Порядок школьный. Львів, 1586. В кн.: Пам'ятки братських шкіл на Украӥні. Київ: «Наукова думка», 1988. 38-42. 
Рад., Вінець = РАдивиловский А. Вънецъ Хйъ. Київ, 1688.

Рад., Огородок = РАдивиловский А. Огородокъ Марій Бйьл. Київ, 1676.

Рад., Опов. = КРекотень В. І. Оповідання Антонія Радивиловського. Київ: «Наукова думка», 1983.

Семя = Съма слова Божіл на нивђ сердецъ человъческихъ съаннагш. Почаїв: Друкарня Успенського монастиря, 1772.

Сімейний кодекс = Сімейний кодекс. https://zakon.rada.gov.ua/laws/show/2947-14.

Срезн. = СРезнЕвский И. И. Материаль для словаря древнерусского языка. Т. 1-3. Санкт-Петербург, 1893-1912.

СУМ = Словник украйнської мови. Т. 1-11. Київ: «Наукова думка», 1970-1980.

СУМ XVI-XVII = Словник української мови XVI- першої половини XVII cm. Вип. 116. Львів: Інститут українознавства ім. І. Крип’якевича НАНУ, 1994-2015.

Тимч., Матер. = Тимченко Є. Матеріали до словника писемної та книжної української мови XV-XVIII cm. Кн. 1-2. Київ-Нью-Йорк: Видавництво Інституту української мови НАНУ, 2002-2003.

Туптало, Проповіді = Титовъ Ан. Проповъди святителя Димитрія, митрополита Ростовскаго, на украинскомъ наръчіи. Москва, 1909.

УЄ = Евангеліе учителное, албо казаня на кождую неделю и свята урочистыи. Св'є: Друкарня Вільнюського братства, 1616.

\section{Література}

АРьеС 1999 = АРьЕС Ф. Ребенок и семейная жизнь при старом порядке. Екатеринбург: «Издательство Уральского университета», 1999.

ГиППОКРАТ 1944 = ГиППОКРАТ: Сочинения. Т. 2. Москва: «Медгиз», 1944.

Гошко 2017 = Гошко Т. Уявлення про дитинство у кодексах міського права в Речі Посполитій XVI - початку XVII ст. Місто. Історія, культура, суспільство 2017/4: 37-56.

ЗАХАРОВА 2017 = ЗАХАРОВА К. І. Дитинство як соціально-культурний феномен та мовний концепт. В кн.: Нова філологія. № 70. Запоріжжя, 2017. 80-85.

ЗолТАН 2014 = ЗолтАн А. Interslavica. Исследования по межславянским языковым и культурным контактам. Москва: «Индрик», 2014.

КОЗЫРЕв 1968 = КОзЫРЕВ И. С. Из истории формирования словарных составов русского и белорусского языков. Известия Академии наук СССР 1968/4: 291-300.

НІмчук 1980 = НІмчук В. В. Староукраӥнська лексикографія в ї̈ зв'язках з російською та білоруською. Київ: «Наукова думка», 1980.

СЕРДЮК 2018 = СЕРДЮК І. Маленький дорослий. Дитина й дитинство в Гетьманшині y XVIII cm. Київ: «К.І.С.», 2018.

ЦЕйтлин 1996 = ЦЕйтлин Р. М. Сравнительная лексикология славянских языков. Москва: «Наука», 1996.

SMolareK 2013 = SMolareK K. [rec.] Żołądź-Strzelczyk D., Kabacińska-Łuczak K. Codzienność dziecięca opisana słowem i obrazem. Życie dziecka na ziemiach polskich od XVI do XVIII w. Warszawa, 2012. Klio. Czasopismo poświęcone dziejom Polski $i$ powszechnym 2013/1: 207-210.

ŻoŁĄDź-STrzelczyk 2002 = ŻoŁĄDź-STrZelczyk D. Dziecko $w$ dawnej Polsce. Poznań: Wydawnictwo Poznańskie, 2002. 


\section{OKSANA ZELINS'KA}

Department of the Ukrainian Language and Teaching Methods, Pavlo Tychyna Uman State Pedagogical University

\section{Lexical Means Denoting Child Age in Written Records of the Ukrainian Language in the 16th-18th Centuries}

Research devoted to childhood as a social-cultural phenomenon has become more active in present-day science. Scientists study some peculiarities of the perception of child and childhood by society in different historical epochs, try to fix childhood limits and to define age periods within child age, and make a conclusion that in many cases, periods of man's life are correlated with social roles of people rather than with biological age, and they were formed under the influence of social institutes developing together with the evolution of society.

The present paper analyzes lexical means used in written records of the Ukrainian language in the 16th-18th centuries to denote child age and express the concept of an age differentiation of childhood. The written records of the Ukrainian language of different genres in the mentioned period were the sources of the research: e.g. business language records, P. Berynda's dictionary, religious texts, sermons, and poetic works.

Lexical units expressing child age to denote childhood as an age period of man's life and general names originating from colloquial language and taken from Church Slavonic were used to denote children. Written sources confirm an active use of hypocoristic forms.

The lack of a clear classification of childhood into separate age periods is seen in the system of children's names. Most of the general names denoting children did not represent an age gradation of childhood and only some words were special names of a child expressing an age characteristic: those were the names of a newly-born child and a baby.

Some adjectives combination with nouns to denote children indicated a relative age characteristic (little, minor) but the contexts in which phrases with the adjective little were used did not give a reason to distinguish between a little child and a young man.

In several sources, a seven-year period was classified as a special stage in a child's life, first of all, due to religious practice. According to Christian tradition, a child was considered to have no sins until the age of 7 since he or she cannot distinguish between good and bad. After that, he or she had to shrive. In secular practice, the age of 7 became the time when a child would be sent to an educational institution. The texts of pedagogical orientation prove the synonymy of common names denoting children with special names of the individuals who get education.

A differentiation according to an age characteristic "adulthood" vs. "minority" can be seen clearly, which is explained by the legal status of an adult and, correspondingly, is expressed by the corresponding lexical denotations. The vocabulary denoting this age period is mostly represented by sources written in business language.

One can see that lexical semantics, with help of which child age is marked in records of the Ukrainian language in the 16th-18th centuries, gives a general concept of childhood common for Ukrainian and European social communities of that time.

Keywords: the Ukrainian language in the 16th-18th centuries, child age, childhood, written records, vocabulary denoting children, lexical semantics, polysemy, synonyms 